\title{
Family Eating Behavior of Stunting Children in Silo District, Jember Regency during Covid-19 Pandemic
}

\author{
Dhyani Ayu Perwiraningrum ${ }^{1 *}$, Puspito Arum ${ }^{2}$, Yoswenita Susindra ${ }^{3}$ \\ ${ }^{1,2,3}$ Health Department, Politeknik Negeri Jember, Indonesia \\ ${ }^{*}$ Corresponding author. Email: dhyani@polije.ac.id
}

\begin{abstract}
Stunting has an impact on delayed physical development and low levels of intelligence, increased risk of infection and increased child morbidity and mortality. Three hundred and eighty-seven of the 3168 toddlers in the Silo I subdistrict and 1269 of 4620 toddlers in the Silo II subdistrict were stunted based on EPPGBM data by February 2021. Silo district had the highest prevalence of stunting toddlers in Jember Regency (49\%) based on the E-HDW (E-Human Development Worker) report of the Ministry of Villages and PDTT by March 2021. Based on the information from local nutritionist, high number of stunted children in Silo was caused by lack of understanding about food and nutrition. It was mainly due to low level of economic status. Low purchasing power of the family, family eating habit, and covid-19 pandemic altogether may worsen the food and nutrition quality of the children. This study aims to identify the eating behavior of stunted children's families in Silo district, Jember regency during the covid-19 outbreak period. A total of 28 families who had stunted children were involved in the study. Data were collected by local cadres using online forms. Food frequency questionnaire was used to observe the eating behavior of families which have stunted children, including food sources of carbohydrates, protein, vegetables, and fruit. The results described that the food which were consumed by the family of stunted children were not varied. There was limitation of protein source food choice in Silo.
\end{abstract}

Keywords: Stunting, Eating Behavior, Family Eating Behavior, Covid-19

\section{INTRODUCTION}

Stunting has an impact on delayed motor physical development and low levels of intelligence, increased risk of infection and increased child morbidity and mortality [1]. Stunting toddlers need a catch-up growth attempt to improve their condition. Stunting improvement efforts such as extra food (PMT-P) that is formulated with good nutrition are considered to reduce the adverse effects of stunting [2]. One of the determinants of stunting is unhealthy food. Lack of nutrient intake and community understanding of toddlers' nutritional needs are related to the role of families, particularly in terms of feeding behaviors [3]. Applying a good diet practice in toddlers is not easy. It is influenced by perception and knowledge of family health, family attitudes in choosing food sources, family culture, environment, food availability and sources of information [4], [5].

Jember had the highest prevalence of stunting in East Java at $37.94 \%$ at the beginning of 2021 , higher than the national prevalence. Three hundred and eightyseven of the 3168 toddlers in the Silo I sub-district and 1269 of 4620 toddlers in the Silo II sub-district were stunted based on EPPGBM as of February 2021. Silo district had the highest prevalence of stunting toddlers in Jember $(49 \%)$ based on the E-HDW (E-Human Development Worker) report of the Ministry of Villages and PDTT as of March 2021.

Stunting in childhood can lead to a complex lost generation which will threaten the quality of human resources in the future. Some influential factors of stunting are nutritional knowledge, socioeconomic status including poverty, cultural problems in society and beliefs, how to process the food and behavioral problems. All those factors may affect the nutritional status of the children during their growth and development. This is the important period of their life for physical, social and mental growth.

Eating problems is one of the causes of stunting. Children need nutritious food to support their growth 
and development. Eating problems can occur due to a child imitating the poor dietary habit of their parents. Eating behavior arise from eating behavior practised at home can cause children to replicate the habits and create certain favorite food. Eating behavior is strongly influenced by the daily family lifestyle. That lifestyle sometimes is not accompanied by proper education so that children tend to eat without understanding what kind of food which they consume [6].

Family plays a big role in providing food and nutritional [7]. The nutritional quality of a child is determined by the perspective and preferences of the family about food. This quantity is related to the pattern of daily eating habits in the family. The family eating habit is adapted generation by generation. The food quality is determined by the level of knowledge and attitude of the family about food as well. The selection of appropriate food sources may impact family health. In addition, good food processing also needs to be considered [8]. Arising a good diet is the obligation of parents to guarantee the children obtain an adequate nutrients. With good parenting practice, children will optimally grow and develop into high quality resilient.

The Covid 19 pandemic has had major implications for family food security, which is thought to have an effect on eating behavior and providing nutritious food for families, especially families of stunted children. This study seeks to see a picture in terms of family eating behavior, especially during the Covid 19 pandemic.

\section{METHODS}

This was a cross-sectional study conducted in Silo subdistrict, Jember Regency, East Java. A total of 28 families who had stunted children were involved in the study. Data of stunted children were obtained from the nutritional status surveillance of toddlers in Silo subdistrict. A consecutive sampling technique was used to recruit the subjects. The number of subjects obtained was adjusted to the duration of the study time.

This research was conducted during the pandemic Covid-19, therefore data were collected by health cadres in Silo district whose home location is adjacent to the location of the subject's house. Cadre collected data through online forms that had been created by researchers. Before collecting the data, the cadres attended the training which was carried out by researchers. The training was about how to conduct interviews and how to fill out online forms.

The variable of this study was the eating behavior of families who have stunting children, including food sources of carbohydrates, sources of protein, vegetables, and fruit. The FFQ instrument is used to observe family eating behavior. Respondents were asked about the type of food which family consumed in the past 3 months. Types of food are grouped into 7 groups, namely staple foods, animal-based protein, plant-based protein, vegetables, fruit, milk and oil. The data was analyzed using data processing software and Microsoft Excel.

\section{RESULTS AND DISCUSSION}

\subsection{Results}

Interviews were conducted with 28 families, and there were 29 stunted children. Most stunted children $(51.72 \%, \mathrm{n}=15)$ were between the ages of $2-5$ years, and most of them $(58.6 \%, \mathrm{n}=17)$ were male.

This study aims to identify the eating behavior of families who have stunting children. The study observed 7 groups of foodstuffs consumed by families who have stunting children, namely staple foods, animal-based protein, plant based-protein, vegetables, fruit, milk and processed, and oil. Table 1 shows the type and frequency of staple foods consumption. Rice is the most consumed staple, followed by bread, biscuits, and wheat flour. While corn, yam, and cassava are staple foods that are rarely consumed. Table 2 describes the type and frequency of animal-based and plant-based protein consumption. Animal-based proteins that are often consumed are pindang fish, anchoic fish, chicken eggs, meatballs, and sausages. While animal-based proteins that are rarely consumed are beef, shrimp, and corned beef. Plant-based proteins that is often consumed are tofu and tempeh. Nuts are included in plant-based proteins that is rarely consumed.

Table 3 shows the type and frequency of vegetable and fruit consumption. Amaranth, kangkong, mustard greens, carrots, tomatoes, moringa, and chickpeas are types of vegetables that are often consumed. Papaya and banana are fruits that are often consumed. Bean sprouts, cucumbers, broccoli, melon, bengkuang, and strawberry are vegetables and fruits that are rarely consumed. Table 4 shows the type and frequency of consumption of milk and dairy product and oil. Milk and sweetened condensed milk are dairy products that are often consumed, whole milk yoghurt, cheese, and fresh milk become rarely consumed dairy products. Palm oil is the most used type of oil to cook.

\subsection{Discussion}

Eating behavior, both individual eating behavior or family eating behavior is closely related to eating / nutritional intake. Family eating behavior affects the type of food consumed by family members [9], [10]. Food consumption is closely related to the intake of nutrients. Intake of food or nutrients is related to the health condition of the child, including stunting conditions [11]. Stunting conditions are caused by a lack of nutritional intake. Lack of food / nutrient intake in every phase of life, namely the adolescent phase, pregnant women, breastfeeding, and toddlers, can be at risk of causing children to become stunted [12]. 
Table 1. The type and frequency of staple foods consumption

\begin{tabular}{|c|c|c|c|c|c|c|c|c|c|}
\hline \multirow[t]{3}{*}{ Food } & \multicolumn{9}{|c|}{ Frequency } \\
\hline & $\begin{array}{l}>1 x \\
/ \text { day }\end{array}$ & $\begin{array}{c}\mathbf{1 x} \\
/ \mathbf{d a y}\end{array}$ & $\begin{array}{c}\text { 4-6x } \\
\text { /week }\end{array}$ & $\begin{array}{c}2 \mathrm{x} \\
/ \text { week }\end{array}$ & $\begin{array}{c}1 \mathbf{x} \\
/ \text { week }\end{array}$ & $\begin{array}{c}2-3 x \text { / } \\
\text { month }\end{array}$ & $\begin{array}{c}1 x \\
\text { /month }\end{array}$ & $\begin{array}{c}1 x / 3 \\
\text { month }\end{array}$ & Never \\
\hline & $\mathbf{n}$ & $\mathbf{n}$ & $\mathbf{n}$ & $\mathbf{n}$ & $\mathbf{n}$ & $\mathbf{n}$ & $\mathbf{n}$ & $\mathbf{n}$ & $\mathbf{n}$ \\
\hline \multicolumn{10}{|c|}{ Staple food } \\
\hline Rice & 13 & 15 & & & & & & & 1 \\
\hline Bread & 1 & 1 & 7 & 6 & 10 & & 2 & 1 & 1 \\
\hline Noodle & & 1 & 2 & 6 & 4 & 2 & 6 & 5 & 3 \\
\hline Corn & & & 1 & 1 & 5 & 4 & 3 & 2 & 13 \\
\hline Biscuit & 1 & 2 & 6 & 5 & 12 & 2 & 1 & & \\
\hline $\begin{array}{l}\text { Sweet } \\
\text { potato }\end{array}$ & & 1 & 1 & 4 & 3 & 4 & 4 & 1 & 11 \\
\hline $\begin{array}{l}\text { Rice } \\
\text { noodle }\end{array}$ & & 1 & 1 & 5 & 3 & 3 & 4 & 5 & 7 \\
\hline Cracker & & 1 & 4 & 5 & 1 & 2 & 5 & 3 & 8 \\
\hline Rice flour & & 2 & 3 & 6 & 9 & 5 & 2 & 1 & 1 \\
\hline $\begin{array}{l}\text { Wheat } \\
\text { flour }\end{array}$ & & 1 & 3 & 6 & 11 & 4 & 2 & & 2 \\
\hline Casava & & 1 & 1 & 7 & 3 & 3 & 2 & 1 & 11 \\
\hline
\end{tabular}

Table 2. The type and frequency of animal-based and plant-based protein consumption.

\begin{tabular}{|c|c|c|c|c|c|c|c|c|c|}
\hline \multirow[t]{3}{*}{ Food } & \multicolumn{9}{|c|}{ Frequency } \\
\hline & $\begin{array}{l}>1 x \\
\text { /day }\end{array}$ & $\begin{array}{c}\text { 1x } \\
\text { /day }\end{array}$ & $\begin{array}{c}\text { 4-6x } \\
\text { /week }\end{array}$ & $\begin{array}{c}2 \mathrm{x} \\
/ \text { week }\end{array}$ & $\begin{array}{c}1 \mathbf{x} \\
/ \text { week }\end{array}$ & $\begin{array}{c}2-3 x \text { / } \\
\text { month }\end{array}$ & $\begin{array}{c}\text { 1x } \\
\text { /month }\end{array}$ & $\begin{array}{c}1 \mathrm{x} / 3 \\
\text { month }\end{array}$ & $\begin{array}{c}\text { Neve } \\
\mathbf{r}\end{array}$ \\
\hline & $\mathbf{n}$ & $\mathbf{n}$ & $\mathbf{n}$ & $\mathbf{n}$ & $\mathbf{n}$ & $\mathbf{n}$ & $\mathbf{n}$ & $\mathbf{n}$ & $\mathbf{n}$ \\
\hline \multicolumn{10}{|c|}{ Animal-based protein } \\
\hline Chicken & 1 & 2 & 5 & 4 & 4 & 4 & 7 & 1 & 1 \\
\hline Beef & & & 2 & 2 & 4 & 3 & & 15 & 3 \\
\hline $\begin{array}{l}\text { Freshwater } \\
\text { fish }\end{array}$ & & 1 & 3 & & 8 & 5 & 9 & 1 & 2 \\
\hline $\begin{array}{l}\text { Seawater } \\
\text { fish }\end{array}$ & & 1 & 3 & 4 & 11 & 3 & 6 & & 1 \\
\hline Pindang fish & & 1 & 2 & 6 & 15 & 3 & 1 & & 1 \\
\hline Anchoated & & 1 & 3 & 3 & 13 & 3 & 2 & 1 & 3 \\
\hline
\end{tabular}


fish

\begin{tabular}{|c|c|c|c|c|c|c|c|c|c|}
\hline Shrimp & & 1 & 1 & 2 & 3 & 4 & 10 & 5 & 3 \\
\hline $\begin{array}{l}\text { Chicken } \\
\text { liver }\end{array}$ & & 1 & 4 & 1 & 3 & 3 & 7 & 9 & 1 \\
\hline Chicken egg & 2 & & 6 & 3 & 11 & 4 & 1 & & 2 \\
\hline Duck egg & & 2 & 1 & 3 & 2 & 1 & 6 & 8 & 6 \\
\hline Meatball & & 1 & 10 & 1 & 7 & 3 & 5 & 1 & 1 \\
\hline Corned Beef & & 1 & & 2 & 1 & 2 & & 4 & 19 \\
\hline Sausage & 1 & 1 & 2 & 4 & 10 & 4 & 3 & 2 & 2 \\
\hline
\end{tabular}

Plant-based protein

\begin{tabular}{lcccccccc}
\hline Tofu & 7 & 16 & 4 & 1 & & & 1 \\
\hline Tempeh & 7 & 13 & 6 & & 2 & & & 1 \\
\hline Mungbean & 1 & 8 & 4 & 4 & 2 & 3 & 5 & 2 \\
\hline Soybean & 1 & 8 & 5 & 2 & 1 & 1 & 1 & 10 \\
\hline Tolo & 1 & 3 & 6 & 2 & 3 & 2 & 12 \\
\hline Red bean & 1 & 2 & 7 & 1 & 4 & 2 & 13 \\
\hline Peanut & & 6 & 7 & 11 & 2 & 1 & 7 & 2 \\
\hline Ketchup & 1 & 1 & 4 & 3 & 3 & 2 & 2 & 13 \\
\hline Koro & & & & 4 & 5 & 2 & 2 \\
\hline
\end{tabular}

Table 3. The type and frequency of vegetable and fruit consumption.

\begin{tabular}{|c|c|c|c|c|c|c|c|c|c|}
\hline \multirow[t]{3}{*}{ Food } & \multicolumn{9}{|c|}{ Frequency } \\
\hline & $\begin{array}{l}>1 x \\
\text { /day }\end{array}$ & $\begin{array}{c}\mathbf{1 x} \\
/ \mathbf{d a y}\end{array}$ & $\begin{array}{c}\text { 4-6x } \\
\text { /week }\end{array}$ & $\begin{array}{c}2 \mathrm{x} \\
/ \text { week }\end{array}$ & $\begin{array}{c}1 \mathrm{x} \\
/ \text { week }\end{array}$ & $\begin{array}{c}2-3 x \text { / } \\
\text { month }\end{array}$ & $\begin{array}{c}\text { 1x } \\
\text { /month }\end{array}$ & $\begin{array}{c}1 x / 3 \\
\text { month }\end{array}$ & Never \\
\hline & $\mathbf{n}$ & $\mathbf{n}$ & $\mathbf{n}$ & $\mathbf{n}$ & $\mathbf{n}$ & $\mathbf{n}$ & $\mathbf{n}$ & $\mathbf{n}$ & $\mathbf{n}$ \\
\hline \multicolumn{10}{|c|}{ Vegetables } \\
\hline Amaranth & 1 & 9 & 9 & 7 & 2 & & & & 1 \\
\hline Kangk0ng & & 5 & 9 & 11 & 3 & & & & 1 \\
\hline $\begin{array}{l}\text { Mustard } \\
\text { green }\end{array}$ & & 3 & 7 & 13 & 5 & & & & 1 \\
\hline Carrot & 1 & 2 & 9 & 11 & 4 & 1 & & & 1 \\
\hline Tomat0 & & 4 & 8 & 10 & 6 & & & & 1 \\
\hline
\end{tabular}




\begin{tabular}{|c|c|c|c|c|c|c|c|c|c|}
\hline Chickpeas & & 2 & 5 & 12 & 8 & & 1 & & 1 \\
\hline Mushroom & & 1 & 10 & 4 & 1 & 1 & 10 & & 2 \\
\hline Long bean & & 1 & 8 & 7 & 7 & 2 & 3 & & 1 \\
\hline Cabbage & & 2 & 3 & 6 & 4 & 4 & 9 & & 1 \\
\hline Squash & & 2 & 5 & 5 & 6 & 5 & 5 & & 1 \\
\hline Bean sprout & & 1 & 5 & 5 & 3 & 3 & 1 & 1 & 10 \\
\hline Cucumber & & 1 & 4 & 4 & 6 & & 2 & 1 & 11 \\
\hline Pumpkin & & 1 & & 7 & 5 & 2 & 1 & 1 & 12 \\
\hline Broccoli & & 1 & 2 & 6 & 4 & 2 & 1 & 2 & 11 \\
\hline Cauliflower & & 1 & 2 & 7 & 4 & 3 & 9 & & 3 \\
\hline Moringa & 1 & 4 & 7 & 8 & 4 & 1 & & & 4 \\
\hline
\end{tabular}

\section{Fruits}

\begin{tabular}{|c|c|c|c|c|c|c|c|c|c|}
\hline Watermelon & 2 & 3 & 2 & 5 & 2 & 4 & 5 & 5 & 1 \\
\hline Papaya & 1 & 7 & 8 & 5 & 6 & 1 & & & 1 \\
\hline Banana & & 1 & 5 & 8 & 8 & 4 & 1 & 1 & 1 \\
\hline Orange & 1 & 4 & 5 & 4 & 1 & 3 & 5 & 5 & 1 \\
\hline Apple & & 3 & 7 & 3 & & 2 & 5 & 3 & 6 \\
\hline Melon & & 2 & 2 & 6 & 1 & 3 & 3 & 2 & 10 \\
\hline Salak & & 3 & 1 & 6 & 2 & 3 & 8 & 3 & 3 \\
\hline Avocado & 2 & 4 & 4 & & 3 & 3 & 3 & 2 & 8 \\
\hline Guava & & 3 & 2 & 3 & 2 & 3 & 5 & & 11 \\
\hline Sawo & & 1 & 1 & 6 & 2 & 1 & 3 & 4 & 11 \\
\hline Rambutan & & 1 & 3 & 4 & 1 & 1 & 1 & 7 & 11 \\
\hline Bengkuang & & & 5 & 5 & & & 2 & 2 & 15 \\
\hline grape & & & 4 & 3 & 2 & 2 & 2 & 12 & 4 \\
\hline Strawberry & & & 2 & 3 & 3 & 1 & 2 & 4 & 14 \\
\hline Mango & & 1 & 3 & 5 & 2 & 3 & 7 & 7 & 1 \\
\hline Jack fruit & & 1 & 2 & 3 & 2 & 1 & 11 & 7 & 2 \\
\hline
\end{tabular}

Based on Table 1, Staple foods are the most consumed foods at the time of eating. Staple foods are generally carbohydrate source foods. The results of this study showed that the staple food most consumed by the respondent's family was rice. Rice is a staple food of Indonesian society. Rice is the most commonly consumed staple food because rice is available in almost all regions of Indonesia. Rice is a source of carbohydrates. As a food source of carbohydrates, rice becomes the largest source of energy. 
Staple foods other than rice that are often consumed by the respondent's family are bread, biscuits, and wheat flour. Bread and biscuits are wheat-based foods. Wheat includes foodstuffs that are easy to obtain. People can buy wheat from modern stores or traditional stores. Affordable wheat prices make wheat a staple food choice from respondents. In addition to the affordable price, wheat can also be processed into various types of food. This causes wheat to be widely liked by the community. Corn, yam, and cassava became a staple food that is rarely consumed by respondents. This is because corn, yams, and cassava are seasonal crops[13]. Farmers generally grow corn, mother, and cassava interrupted when planting rice. This causes corn. Yams, and cassava are not available all the time. The limited way of processing corn, yam, and cassava, also causes the three types of food ingredients to be rarely consumed, because people feel bored with the existing processed.

Animal side dishes and plant-based side dishes are food sources of protein. Consumption of food sources of protein is associated with the incidence of stunting. Various studies have shown that stunting events are related to inadequate protein intake [14], [15]. Animal side dishes provide protein with higher bioavailability than plant-based side dishes [16].

Animal side dishes that are often consumed by the respondent's family are pindang fish, anchoic fish, chicken eggs, meatballs and sausages. These foodstuffs can be found almost every day at the local market. Pindang fish is a type of marine fish that is processed by boiling and salted so that it has a longer shelf life than fresh fish [17]. This longer shelf life causes pindang fish to be found in the market or at vegetable sellers almost every day. Chicken eggs are an easy source of animal protein. Chicken eggs are always available in the market and in traditional stores. Chicken eggs have a long shelf life [18]. Families can keep chicken eggs at home in preparation for animal side dishes. This causes chicken eggs to become animal side dishes that are often consumed by the respondent's family. Meatballs become animal side dishes that are often consumed by respondents' families because there are many food stalls that sell meatball menus in Silo District.

Based on Table 2, Meatballs are one of the processed foods of beef. The price of beef is quite expensive causing families to switch to consuming meatballs because the price is quite affordable. In addition to meatballs, the family consumes processed beef in the form of sausages. Sausages available at the local market are sausages at affordable prices. Corned beef becomes a source of animal side dishes that are rarely consumed because the price is quite expensive. Shrimp is an animal side dish that is rarely consumed because the location of Silo subdistrict is a mountainous area, where the availability of seafood is very limited. Tofu and tempeh become a source of animal side dishes that are often consumed by the respondent's family. Tofu and tempeh are traditional foods that are hereditary to be part of the diet of Indonesian people. Tofu and tempeh are foods derived from soybeans. Soybeans processed into tofu and tempeh have higher bioavailability and have better receiving power than soybeans themselves [19].

Vegetables and fruits are food sources of vitamins and minerals [20]. Vitamins and minerals play a role in the metabolism of nutrients in the body. Vitamins and minerals are enzyme-forming materials and enzyme prerusor in nutrient metabolism. Lack of consumption of vegetables and fruits is at risk of impaired metabolism of nutrients, so that nutrients obtained from food consumed cannot be utilized by the body [20], [21]. This can lead to growth disorders, particularly in children [10], [12].

Spinach, kale, green mustard, carrots, tomatoes, moringa, and chickpeas are types of vegetables that are often consumed by the respondents' families, while the fruits that are often consumed are papaya and bananas. These types of vegetables and fruits are vegetables and fruits that are almost every day available in markets and vegetable sellers. These types of vegetables and fruits are also types of vegetables and fruits that are preferred by children.

Foodstuffs consumed by families of stunted children do not have much variation. The choice of food ingredients source of animal and vegetable side dishes also does not vary. This is because these foods are foodstuffs that are easily obtained and available at the nearest market. The location of the respondent's family home is a mountainous area so residents rely on nearby markets and mobile vegetable sellers as a source of food providers they consume. The foodstuffs they often consume are foodstuffs at affordable prices for them.

\section{CONCLUSION}

\subsection{Conclusion}

Foodstuffs consumed by families of stunted children do not have much variation. The choice of food ingredients source animal and vegetable side dishes also does not vary.

\subsection{Suggestion}

Further research not only examines family eating behavior in terms of the type of food consumed, but also examines the amount of food consumed.

\section{AUTHORS' CONTRIBUTIONS}

This study contributes to describing the eating behavior of families who had toddlers stunting during the covid 19 pandemic, so that we can find a picture of how diversity of food and nutritional deficiencies occur. This research can be the basis for the development of nutritional intervention programs that lead to the fulfillment of daily intake according to the 
characteristics and favorites of families for certain foodstuffs.

\section{ACKNOWLEDGMENTS}

This research was funded by DIPA Politeknik Negeri Jember in 2021. There is no conflict of interest, either between researchers and fund providers, or with stakeholders and health workers at the research site.

\section{REFERENCES}

[1] H. Probosiwi, E. Huriyati, and D. Ismail, "Stunting dan Perkembangan pada anak usia 1260 bulan di Kalasan," J Ber Kedokt Masy, vol. 33, no. 11, 2017.

[2] C. Desmond and D. Casale, "Catch Up Grow in Stunted Children: Definition and Predictor," PLoS One, vol. 12, no. 12, 2017.

[3] Yappika Action Aid, "Annual Report: Kajian Kebijakan dan Studi Kasus Stunting di Tingkat Nasional dan Kabupaten Jember,” Jakarta, 2017.

[4] D. Putri and D. Sukandar, "Keadaan Rumah, Kebiasaan Makan, Status Gizi dan Status Kesehatan Balita di Kecamatan Tamansari Kabupaten Bogor," J Gizi dan Pangan, vol. 7, no. 3, p. 163-168, 2012.

[5] D. Perwiraningrum, A. Elisanti, D. Amareta, and W. A, "Need Assessment of Stunted Children During Pandemic Covid-19 to Develop Nutrition Intervention Program in Jember District, East Java, Indonesia," in The 1st International Converence on Social Science, Humanity and Public Health 2020, 2020.

[6] Mayawati and Anita, "Pengaruh Pengetahuan Gizi, Status Sosial Ekonomi, Gaya Hidup dan Pola Makan terhadap Status Gizi Anak (Studi Kausal di Pos PAUD Kota Semarang Tahun 2015)," J. Pendidik. Anak Usia Dini, vol. 10, no. $2,2016$.

[7] Kementerian Kesehatan RI, "Situasi Balita Pendek," Jakarta, 2016.

[8] C. Nabuasa, M. Juffri, and E. Huriyati, "Riwayat pola asuh, pola makan, asupan zat gizi berhubungan dengan stunting pada anak 24-59 bulan di Biboki Utara, Timor Tengah Utara, Nusa Tenggara Timur," J Gizi dan Diet Indones., vol. 1 , no. 3,2013

[9] L. L. B. Jennifer S. Savage, Jennifer Orlet Fisher, "Parental Influence on Eating Behavior," J Law Med Ethics, vol. 35, no. 1, pp. 22-34, 2007.

[10] M. A. T. Qurahman, "Hubungan perilaku hidup sehat dan gizi seimbang dengan status gizi anak Sekolah Dasar negeri bulukantil di Ngoresan Surakarta,"Universitas Sebelas Maret, 2010.
[11] H. Haris, “ Analisis Perilaku Makan dalam Keluarga untuk Pencegahan Kejadian Stunting di wilayah Kerja Puskesmas Galesong Kecamatan Galesong, Kabupaten Takalar= The Analisys on Family's Eating Behavior to Prevent stunting Incident in Working Area of Public Health CE" Universitas Hasanuddin, 2021.

[12] T. Y. R. Pristya, A. M. Fitri, and W. Wahyuningtyas, "Literature Review: Gizi Antenatal terhadap Kejadian Stunting," J. Kesehat., vol. 12, no. 2, 2021.

[13] Badan Ketahanan Pangan Kementerian Pertanian Bekerjasama dengan Badan Pusat Statistik "Analisis Ketersediaan Pangan Neraca Bahan Makanan Indonesia 2018-2020”, Jakarta, 2020.

[14] R. Uauy, D. J. Suri, S. Ghosh, A. Kurpad, and I. H. Rosenbergd, "Low Circulating Amino Acids and Protein Quality: An Interesting Piece in the Puzzle of Early Childhood Stunting," EBioMedicine, vol. 8, pp. 28-28, 2016.

[15] S. Fikawati, A. Syafiq, R. K. Ririyanti, and S. C. Gemily, "Energy and protein intakes are associated with stunting among preschool children in Central Jakarta, Indonesia: a casecontrol study," Malays. J. Nutr., vol. 27, no. 1 , pp. 81-91, 2021

[16] I. Berrazaga, V. Micard, M. Gueugneau, and S. Walrand, "The Role of the Anabolic Properties of Plant- versus Animal-Based Protein Sources in Supporting Muscle Mass Maintenance: A Critical Review," Nutrients, vol. 11, no. 8, p. 1825,2019

[17] I. G. S. Pandit, Teknologi Pemindangan Ikan Tongkol. Denpasar: Warmadewa University Press, 2016.

[18] E. M. S. Barutu, H. Latif, and T. Purnawarman, "Kualitas dan Masa Simpan Telur Ayam Konsumsi pada Suhu Ruang," Institut Pertanian Bogor, 2016.

[19] M. Astuti, A. Meliala, F. S. Dalais, and M. L. Wahlqvist, "Tempe, a nutritious and healthy food from Indonesia," Asia Pac. J. Clin. Nutr., vol. 9, no. 4,2001

[20] J. L. Slavin and B. Lloyd, "Health benefits of fruits and vegetables," Adv Nutr, vol. 3, no. 4, pp. 506-516, 2012.

[21] E. Huskisson, S. Maggini, and M. Ruf, "The role of vitamins and minerals in energy metabolism and well-being," J Int Med Res, vol. 35, no. 5, pp. 277-289, 2007. 